\section{Contractility of Porcine "Ghost" Myofibril Irrigated with Myosin from Normal and PSE Porcine Muscle}

\author{
Sam Kyung Sung, Kenjiro Izumi, Tatsumi \\ ITo and Toshiyuki Fukazawa

\begin{abstract}
Laboratory of Chemistry and Technology of Animal Products, Faculty of Agriculture,
\end{abstract} \\ Kyushu University, Fukuoka 812
}

Received January 11, 1977

Several workers have documented that rabbit "ghost" fibers and myofibrils irrigated with myosin can contract upon addition of $\mathrm{Mg}^{2+}-\mathrm{ATP} .{ }^{1 \sim 5)}$ Tawada et al. ${ }^{5}$ have indicated that in the myosin-irrigated fibers thick filaments are re-formed in lengths from one Z-membrane to the other Z-membrane of a sarcomere, running parallel to the thin filaments. We have shown in a previous experiment that rabbit "ghost" single fiber irrigated with myosin extracted from PSE porcine muscle can not contract by the addition of $\mathrm{Mg}^{2+}$ ATP. ${ }^{8)}$ There was lack of contractility in myofibrils having $\mathrm{pH}$ values below 5.30 , although $\mathrm{Mg}^{2+}$-ATPase activity still remained. ${ }^{7)}$ In addition, it was found that a muscle having less extractability of myofibrillar proteins was the muscle having lower ATPase activity. ${ }^{7)}$ Thus, there is a probability that unextractable myosin which remains in PSE myofibrils after extracting myosin with high ionic salt solution is the denatured one and extractable myosin with it is native one. In order to discriminate the state of myosin, native or denatured, in PSE porcine muscle, we have investigated contractility of "ghost" myofibrils irrigated with myosin prepared from normal and PSE porcine muscle. $\mathrm{Mg}^{2+}-$ ATPase activity of myofibrils before and after the extraction of myosin with a modified Guba-Straub solution $(0.3 \mathrm{M} \mathrm{KCl}, 0.15 \mathrm{M}$ phosphate, $5 \mathrm{mM} \mathrm{MgCl}, 2 \mathrm{mM}$ ethyleneglycol-bis-(2-aminoethylether)-N, N, N', N'-tetraacetic acid (EGTA), $5 \mathrm{mM}$ ATP, $\mathrm{pH}$ 6.5) and $\mathrm{Ca}^{2+}$ ATPase activity of crude myosin extracted from normal and PSE porcine myofibrils were also determined.

Normal and PSE porcine muscle were selected from the carcasses $24 \mathrm{hr}$ postmortem by testing the contractility of myofibrils as described in a previous paper. ${ }^{7)}$ Normal muscle (pH 5.60) myofibrils exhibited 100\% contractility upon addition of $\mathrm{Mg}^{2+}-\mathrm{ATP}$ solution, while those from PSE muscle ( $\mathrm{pH} 5.08$ ) exhibited $0 \%$ contractility. Myofibrils were prepared according to the method of Briskey and Fukazawa, ${ }^{8)}$ except that myofibrils were washed with borate- $\mathrm{KCl}$ solution $(0.1 \mathrm{M}$
$\mathrm{KCl}, 0.039 \mathrm{M}$ borate, $5 \mathrm{mM}$ EDTA, $\mathrm{pH} 7.1$ ) containing $0.02 \%$ Triton $\mathrm{X}-100$ for $5 \mathrm{~min}$ at the first washing step. Myosin was prepared from normal $(\mathrm{pH} 5.60)$ and PSE (pH 5.08) muscles according to the procedure of Quass and Briskey ${ }^{2)}$ with a slight modification: the modified Guba-Straub solution was used for the extraction of myosin. Ultracentrifugation was done at $100,000 \times g$ for $2 \mathrm{hr}$ instead of $35,000 \times g$ for $30 \mathrm{~min}$ in the original method. Contraction of untreated, "ghost" and myosin-irrigated myofibrils was carried out under a phase contrast microscope (Olympus microscope FHT, Olympus Ltd) according to the procedure of Hanson and Huxley. ${ }^{13}$ Exchange of solutions was performed by the addition of a few drops of the appropriate solution from a glass capillary and sucking liquid at the opposite side with a piece of blotting paper. To obtain "ghost" myofibrils, myosin was extracted from myofibrils with Hasselbach-Schneider solution $\left(0.47 \mathrm{M} \mathrm{KCl}, 0.1 \mathrm{M} \mathrm{K}\right.$-phosphate, $1 \mathrm{~mm} \mathrm{MgCl}_{2}, 10 \mathrm{~mm}$ sodium pyrophosphate, $\mathrm{pH}$ 6.4) for $7 \mathrm{~min}$. The resulting "ghost" myofibrils were washed out with a standard salt solution $\left(0.1 \mathrm{M} \mathrm{KCl}, 1 \mathrm{mM} \mathrm{MgCl}_{2}, 6.7 \mathrm{~mm}\right.$ phosphate, pH 7.0). The "ghost" myofibrils obtained showed no contraction upon addition of a contracting solution ( $50 \mathrm{~mm} \mathrm{KCl}, 10 \mathrm{mM} \mathrm{MgCl}_{2}, 0.1 \mathrm{mM} \mathrm{CaCl}$, $1 \mathrm{mM}$ ATP and $6.7 \mathrm{mM}$ phosphate, pH 7.0; Fig. 1b). Then, the "ghost" myofibrils were irrigated with myosin $(4 \mathrm{mg} / \mathrm{ml}$ in $0.6 \mathrm{M} \mathrm{KCl})$ prepared from normal ( $\mathrm{pH} 5.60)$ and PSE (pH 5.08) porcine muscles for $30 \mathrm{~min}$ at $0^{\circ} \mathrm{C}$. To measure the extractability of myosin from porcine myofibrils, normal (pH 5.60) and PSE (pH 5.08) myofibrils pastes $(10 \mathrm{~g})$ were suspended in $5 \mathrm{vol}$ of the modified Guba-Straub solution for $15 \mathrm{~min}$ with a gentle stirring and then centrifuged at $600 \times 9$ for $15 \mathrm{~min}$. The supernatants were diluted with $15 \mathrm{vol}$ of distilled water, followed by centrifugation $(900 \times g$, $15 \mathrm{~min}$ ). The resultant sediment was dissolved in $0.5 \mathrm{~m}$ $\mathrm{KCl}$ solution (crude myosin). The residue of myofibrils was washed with $0.1 \mathrm{M} \mathrm{KCl}$ solution, and again centrifuged at $600 \times g$ for $15 \mathrm{~min}$. $\mathrm{Mg}^{2+}$-ATPase activity of normal and PSE myofibrils before and after the extraction of myosin with the modified GubaStraub solution was measured at $25^{\circ} \mathrm{C}$ in the following reaction mixtures; $0.3 \sim 0.5 \mathrm{mg}$ protein $/ \mathrm{ml}, 0.05 \mathrm{mM}$ $\mathrm{CaCl}_{2}, 1 \mathrm{mM} \mathrm{MgCl}_{2}, 0.1 \mathrm{M} \mathrm{KCl}, 1 \mathrm{mM}$ ATP, $0.02 \mathrm{M}$ Tris-maleate, $\mathrm{pH} 7.0 . \mathrm{Ca}^{2+}$-ATPase activity of the crude myosin was measured at $25^{\circ} \mathrm{C}$ in the medium containing $0.5 \mathrm{mg}$ protein $/ \mathrm{ml}, 4 \mathrm{mM} \mathrm{CaCl}, 0.5 \mathrm{M} \mathrm{KCl}$, $1 \mathrm{mM}$ ATP, $0.02 \mathrm{~m}$ Tris-maleate, $\mathrm{pH}$ 7.0. The liberated phosphate was measured by the method of Fiske and Subbarow. ${ }^{10)}$ Determination of protein concentration was made by the biuret reaction. ${ }^{11}$

As illustrated in Fig. 1, normal myosin-irrigated myofibrils contracted upon addition of the contracting solution (Figs. 1c and d), while PSE myosin-irrigated myofibrils could not contract (Figs. 1e and f). On the other hand, it was difficult to obtain "ghost" myofibrils 


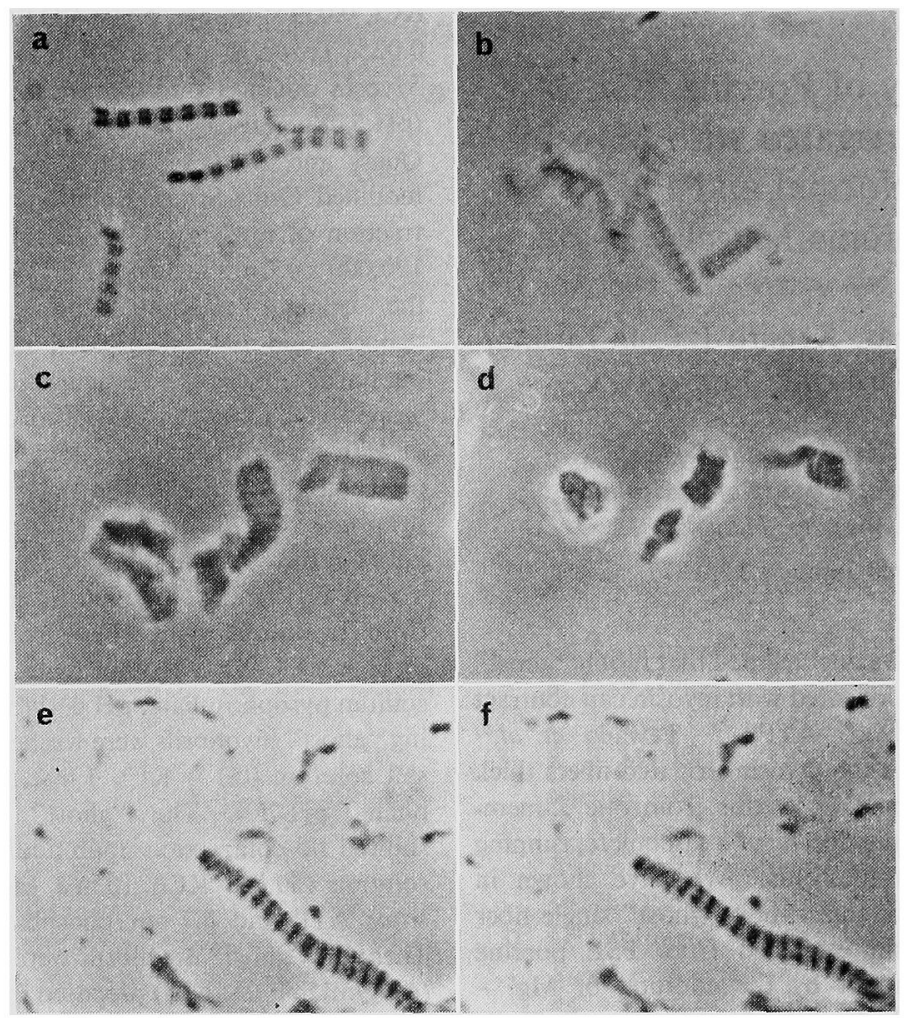

Fig. 1. Phase Micrographs of Intact, "Ghost" and Myosin-irrigated Myofibrils.

a) Intact myofibrils isolated from normal porcine muscle.

b) "Ghost" myofibrils after the extraction of myosin with Hasselbach-Schneider solution from normal myofibrils.

Note: there was no change in the features of "ghost" myofibrils between before and after the addition of the contracting solution. (This photograph was taken after the addition of the contracting solution.)

c) "Ghost" myofibrils irrigated with normal myosin.

d) Normal myosin-irrigated "ghost" myofibrils after the addition of the contracting solution.

e) "Ghost" myofibril irrigated with PSE myosin.

f) PSE myosin-irrigated "ghost" myofibril after the addition of the contracting solution.

Magnification: $\times 2150$.

Table I. ATPase Activity of Myofibrils and Myosin, AND EXTRACTABILITY OF MYOSIN

\begin{tabular}{|c|c|c|c|c|}
\hline & \multicolumn{3}{|c|}{ ATPase activity $\left(\mu\right.$ moles $P_{1} / \mathrm{min} / \mathrm{mg}$ protein $)$} & \multirow{2}{*}{$\begin{array}{l}\text { Extractability of } \\
\text { crude myosin }(\%)\end{array}$} \\
\hline & $\begin{array}{l}\text { Myofibril before } \\
\text { extracting myosin }\end{array}$ & $\begin{array}{l}\text { Myofibril after } \\
\text { extracting myosin }\end{array}$ & Crude myosin & \\
\hline Normal & 0.137 & 0.030 & 0.113 & 54.1 \\
\hline PSE & 0.045 & 0.000 & 0.085 & 5.5 \\
\hline
\end{tabular}


from PSE myofibrils because of the less extractability of myosin. As shown in Table $\mathrm{I}$, extractability of myosin from normal myofibrils was about ten times higher than that of PSE. $\mathrm{Mg}^{2+}$-ATPase activity of the intact myofibrils prepared from normal muscle was much higher than that of PSE, while the difference in $\mathrm{Ca}^{2+}$-ATPase activity of the extracted crude myosin between them was rather small. In addition, the extractable myosin from PSE muscle showed no initial burst of $P_{1}$-liberation. ${ }^{12}$ PSE myofibrils exhibit no ATPase activity after the extraction of myosin. These results suggest that the extractable myosin from PSE myofibrils retains its ATPase activity, while the unextractable myosin in PSE myofibrils loses the activity.

In summary, it is concluded that myosin of PSE porcine muscle has two states in situ, i.e., one is the myosin which is extractable and has ATPase activity, but has no initial burst of $P_{1}$-liberation, the other is the myosin which is unextractable and has no ATPase activity.

\section{REFERENCES}

1) J. Hanson and H. E. Huxley, The structural basis of contraction in striated muscle, Symp. Soc. Exptl. Biol., 9, 228 (1955).

2) A. Oplatka, J. Borejdo and H. Gadasi, FEBS Lett., 45, 55 (1974).

3) A. Oplatka, H. Gadasi and J. Borejdo, Biochem. Biophys. Res. Commun., 58, 905 (1974).

4) T. Hayashi and K. Maruyama, J. Biochem., 78, 1031 (1975).

5) K. Tawada, A. Yoshida and K. Morita, ibid., 80, 121 (1976).

6) K. Izumi, T. Ito and T. Fukazawa, J. Food. Sci., 42, 113 (1977).

7) S. K. Sung, T. Ito and T. Fukazawa, ibid., 41, 102 (1976).

8) E. J. Briskey and T. Fukazawa, Adv. Food Res., 19, 279 (1971).

9) D. W. Quass and E. J. Briskey, J. Food Sci., 33, 180 (1968).

10) C. H. Fiske and Y. Subbarow, J. Biol. Chem., 66, 375 (1925).

11) A. G. Gornall, C. R. Bardawill and M. M. David, ibid., 177, 751 (1949).

12) S. K. Sung, T. Ito and T. Fukazawa, in preparation. 